\title{
Establishment of HPRT and DHFR Gene Mutation Assays as biomarkers In Sheep lung fibroblasts (SLF)
}

فحص الطقرة الوراثية لجين الـHPRT و DHFR كمؤشرات وراثية في خلايا رئة الاغنام

$$
\begin{aligned}
& \begin{array}{lll}
\text { E. K. Shubber, } & \text { Z. M. T. Jaffer }
\end{array} \\
& \text { Ministry of Science and Technology }
\end{aligned}
$$

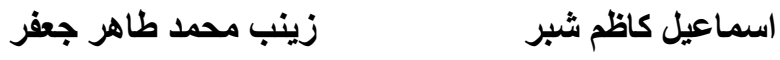

$$
\begin{aligned}
& \text { وزارة العلوم والتكنلوجيا }
\end{aligned}
$$

\section{Abstract}

Ta he aim of this study is to establish a gene mutation assay for examining the integrity of animal cell genome for nuclear transfer technique. Lung fibroblasts which were expanded from 4 months old female lamb were selected as target cells. These cells were coded (SLF) as Sheep lung cells. Growth characterization, doubling time, chromosomal number and structural integrity were checked after their growth in RPMI-1640 medium. For HPRT-gene mutation assay, the cells were plated at density of $1 \times 10^{3}$ cells/plate and grown in medium containing toxic concentrations of 6-thioguanine; while for DHFR -gene mutation assay, toxic concentration of methotrexate was used as a selective agent. Those cells were grown for 15 days; mutant colonies either $6 \mathrm{TG}^{\mathrm{r}}$ or $\mathrm{MTX}^{\mathrm{r}}$ were reinoculated in a selective medium for further 8 weeks for checking the stability of phenotypic expression of mutant cells. The results revealed that SLF cells has spontaneous frequencies of HPRT, and DHFR gene mutations equal to 16 and $22 \times 10^{-3}$ event/ generation/ cell, respectivel.These levels are normal comparing with other animal cell types, and these assays could be applied on other somatic cells.

كان الهنف من هذه الدراسة هو ايجاد طريقة Biomarker لفحص الطفرات الوراثية لجين الـ

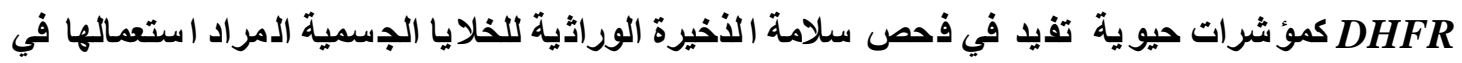

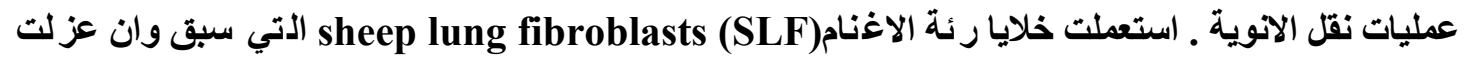

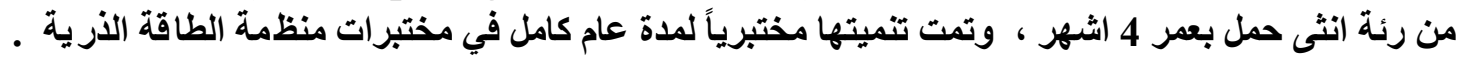

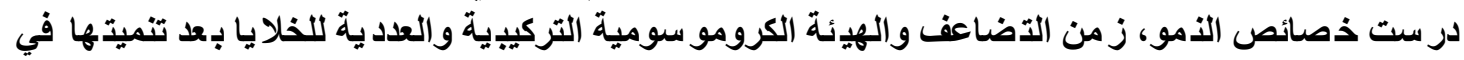

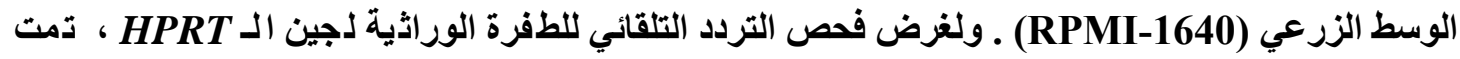

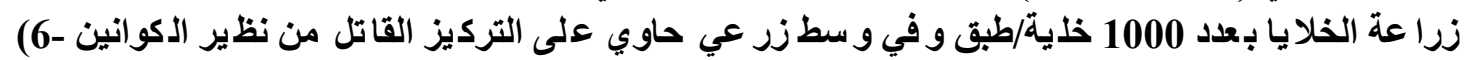

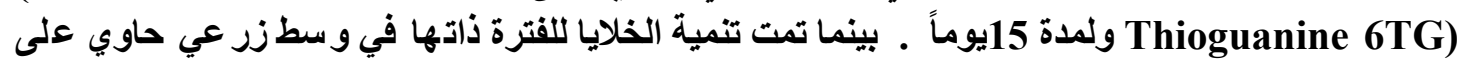

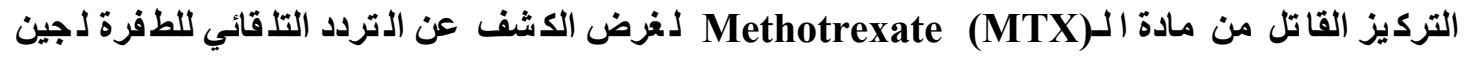
DHFR

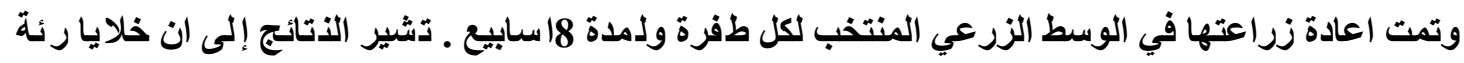

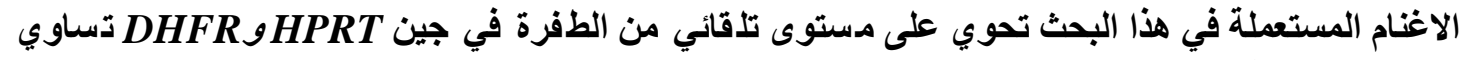

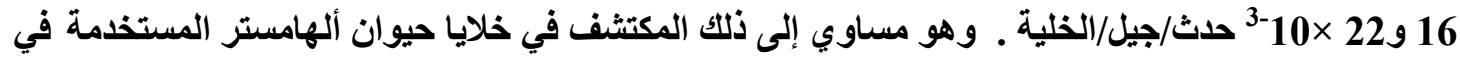

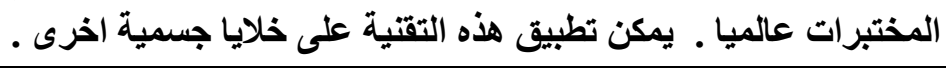




\section{Introduction}

In somatic cell genetics studies, markers which have received considerable attention in mutagenesis, including: loci for hypoxanthine guanine phosphoribosyl transferees (HPRT), adenine phosphoribosyl transferees (APRT), thymidine kinas (TK) and dihydrofolate reeducate (DHFR). HPRT is a purinic salvage enzyme which converts the purine bases hypoxanthine and guanine, to their respective nucleotides IMP and GMP. Although, the enzyme is not required for cell growth, agents such as aminopterin can be used to block de novo synthesis of nucleotides thus making cellular multiplication dependent on the presence of HPRT [1]. HPRT deficiency is the biochemical defect in human Lesch-Nyhan syndrome and its gene has been located on X-chromosome [2].

Dihydrofolate reductase (DHFR) catalyses the reduction of 7.8- dihydrofolate (DHF) to $5,6,7,8$ - tetrahydrofolate (THF), by the coenzyme NADPH [3]. DHFR enzyme is a paramount significance not only because it is necessary for THF formation, but it coupled with thymidylate synthase (TS), it is essential for thymidylate production through the de novo pathway [4]. This enzyme is, therefore, pivotal in the production of purines and pyrimidines precursors for RNA, DNA and amino acid biosynthesis at various stages of cell survival or cycling. The DHFR enzyme levels are highly elevated due to gene amplicfication in the chemically (such as methotrexate) or virally transformed cells as well as malignant cells [5]. DHFR gene and enzyme is a biomarker for highly proliferative cells, thus it has studied for long as a target for antiproliferative agents due to its crucial role in DNA synthesis and its mechanistic features [6, 7]. Genetic studies have shown that DHFR gene is located on chromosome 5 at 11.1- q 13.2 of animal and human cells [8]. In the last two years, we had successfully isolated and explant normal lamb lung fibroblasts. This study is conducted to establish mutation assays for HPRT and DHFR genes in normal lamb lung cells as biomarkers for genome stability and integrity tests.

\section{Materials and Methods}

\section{Cells}

The target cells were established from sheep lung fibroblast (SLF) in the laboratory of Animal Health Department Directorate of Agriculture and Biology, from 4-month old female lamb.

SLF cells were grown exponentially in RPMI-1640 medium which was supplemented with $10 \%$ fetal calf serum and penicillin: streptomycin (100 IU/100 $\mu \mathrm{g} / \mathrm{ml})$ for $48 \mathrm{hr}$. colchicines at final concentration of $10 \mu \mathrm{g} / \mathrm{ml}$ was added to arrest the cells at metaphase in the final $4 \mathrm{hrs}$. of incubation period. Air-dried slides were prepared from those cultures and stained with Giemsa for chromosomal analysis [9]. The mitotic index and the metaphase with 54 chromosomes were determined using blood lymphocyte as model cells [10].

Plating efficiency (PE):

Exponentially growing SLF cells in RPMI- 1640 medium were inoculated 100, 200, 300,500 and 1000 cells for determination of colony forming ability. The cultures were incubated for 2 weeks at $37^{\circ} \mathrm{C}$ at $5 \% \mathrm{CO}_{2}$. The growing colonies were rinsed in buffer 
saline and fixed with methanol: acetic acid (3:1 v:v) for 10 minutes, rinsed and stained with $2.5 \%$ Giemsa solution for $30 \mathrm{~min}$ then rinsed and dried.

The number of colonies was counted as [11]:

\section{Colonies}

\section{$\mathrm{PE}=\frac{\mathrm{X100}}{\text { Inoculated cells }}$}

\section{Cellular growth and doubling time}

For drawing the growth curve and determining the doubling time, exponentially growing SLF cells were inoculated at $10^{3}$ cell / T25 flasks in RPMI-1640 medium and incubated for $(24,48,72,96,120,144) \mathrm{hrs}$. At each time, the cells were harvested with trypsinization and the viable cells were counted using try pan blue method [12].

\section{Gene mutation}

1. HPRT-Locus: The frequency of gene mutation at HPRT locus in SLF cells was determined as described for other cells [13]. By seeding the exponentially growing cells at different 6-thioguanine concentrations (10, 20, 30 and 40) $\mu \mathrm{g} / \mathrm{ml}$ for 15 days. The numbers of $6 \mathrm{TG}^{\mathrm{r}}$ - colonies were counted.

Phenotypic stability of HPRT-mutation was checked by growing the cells for 8 weeks in 6TG medium.

2. DHFR- locus: Spontaneous mutation at DHFR gene in SLF cells was checked by inoculating the exponentially growing cells into methotrexate (MTX) containing medium at concentration of MTX of $(2.5,5.0$ and 10) $\mu \mathrm{g} / \mathrm{ml}$, for 2 weeks. Phenotypic expression of $\mathrm{MTX}^{\mathrm{r}}$ - mutation was checked by continuous growing of mutant colonies in MTX-medium at concentration of $10 \mu \mathrm{g} / \mathrm{ml}$ up to 8 weeks.

\section{Statistical analysis}

Data were analyzed by factorial analysis of variance using least sequare analysis method [14].

\section{Results and Discussion}

Cytogenetic analysis of sheep lung fibroblasts showed a chromosomal number of 54 with no chromosomal aberrations could be seen. In this investigation, the results presented in Table (1) showed that the average cloning efficiency of sheep lung fibroblasts in RPMI-1640 medium grown for 15 days was $51.3 \pm 1.3$. This potency was different from that of human fetal lung fibroblasts (IMR-90) which had a plating efficiency about 35\% [15], or Chinese hamster lung fibroblasts (V-79) cells with a plating efficiency of $90 \%$ [16]. These variations might due to species differences [17]. Table (1): Plating efficiency of sheep lung fibroblasts.

\begin{tabular}{ccc}
\hline Number of seeded cells & $\begin{array}{c}\text { Number of growing } \\
\text { colonies }\end{array}$ & Plating Efficiency PE (\%) \\
100 & 52 & 52.0 \\
200 & 96 & 48.0 \\
300 & 147 & 49.0 \\
500 & 262 & 56.0 \\
1000 & 515 & 51.5 \\
\hline
\end{tabular}

Average plating efficiency $=\mathbf{5 1 . 3} \pm 1.3$ 
Sheep lung cells had grown exponentially from the time of inoculation up to 5 th day with growth ratio of 15.46; post that time the decline in the growth showed up. The doubling time of those cells was estimated to be 10-16 hrs. Table (2).

Table (2): Growth performance of sheep lung fibroblasts in RPMI-1640 Medium for 7 days.

$\begin{array}{ccc}\text { Period of incubation (hr) } & \text { Number of growing cells } & \text { growth rat } \\ 0 & 1500 & - \\ 24 & 3200 & 2.13 \\ 48 & 5600 & 3.73 \\ 72 & 11800 & 7.86 \\ 96 & 23200 & 15.46 \\ 120 & 23200 & 15.46 \\ 144 & 11600 & 7.73\end{array}$

Optimum growth was ranging between day 4 th-5th post inocubation.

These cells different from that of sheep blood lymphocytes [18], and goat blood cells [19] which had doubling time 16-18hrs, while V79 cells had doubling time with range of 10-12 hrs. [16]. These differences within the species in doubling time might due to deference between established cell lines from primary cultured cells even they grow under similar medium and other growth conditions [20].

Table (3):* Spontaneous Mutation fractions of HPRT AND DHFR genes in sheep lung cells.

\begin{tabular}{ccccc}
\hline $\begin{array}{c}\text { Concentration of the } \\
\text { selective agent } \\
(\mu \mathrm{g} / \mathrm{ml})\end{array}$ & $\begin{array}{c}\text { No. of seeded } \\
\text { cells/plate }\end{array}$ & $\begin{array}{c}\text { No.of colonies } \\
\text { /plate }\end{array}$ & $\begin{array}{c}\text { Cloning } \\
\text { efficiency } \\
(\%)\end{array}$ & $\begin{array}{c}\text { Mutation fraction } \\
\text { event/generation /cell }\end{array}$ \\
$\begin{array}{c}\text { 6-Thioguanine } \\
\text { 0 }\end{array}$ & 1000 & 480 & 94.1 & - \\
10 & $=$ & 064 & 66.6 & $54.5 \times 10^{-3}$ \\
20 & $=$ & 028 & 29.1 & $33 \times 10^{-3}$ \\
30 & $=$ & 016 & 16.0 & $16 \times 10^{-3}$ \\
40 & $=$ & 000 & 0.0 & 0.0 \\
Methotrexate & 1000 & 492 & & - \\
0 & $=$ & 85 & 96.4 & $85 \times 10^{-3}$ \\
2.5 & $=$ & 59 & 17.2 & $59 \times 10^{-3}$ \\
5.0 & $=$ & 22 & 4.4 & $22 \times 10^{-3}$ \\
\hline 10.0 & & & & \\
\hline
\end{tabular}

* Data presented as an average of three independent experiments

** Counted as a percentage of controls

In this investigation, it was necessary to determine the concentration of the selective agent for the selection of mutant cells. High concentration of 6 thioguanine $(40 \mu \mathrm{g} / \mathrm{ml})$ was found to reduce completely cellular replication Table (3).

However, at $20 \mu \mathrm{g} / \mathrm{ml}$ of this analogue, only the spontaneously mutated cells with a mutation fraction of $28 \times 10^{-3}$ events/generation/ cell were survived. These mutant cells were grown normally with a phenotypic expression of 6TG-resistance for more than 8 weeks in 6TG-medium. Further increase of $6 \mathrm{TG}$ concentration to $30 \mu \mathrm{g} / \mathrm{ml}$ was significantly reduced cellular viability down to $\mathrm{PE}$ of $16 \%$ (i. e with mutation fraction of $\left.16.0 \times 10^{-3}\right)$. The causes of such reduction are unknown. 6TG was found to induce chromatid damage [21] and arrest the cells at S-phase by inducing unrepaired DNA lesion [22]. This analogue was found to inhibit completely the cellular division and 
replication by days of treatment of human lymphoblastoid and leaving the resistant cells to replicate normally. Cells resistant to 6-TG were found to have no HPRT enzyme activity $[3,23,24]$. Thus 6 TG-resistant sheep lung cells have a spontaneous mutation at HPRT gene as other cells with fraction of $33 \times 10^{-3}$ at a concentration of $20 \mu \mathrm{g} / \mathrm{ml}$ of $6 \mathrm{TG}$ and $16 \times 10^{-3}$ at a concentration of $30 \mu \mathrm{g} / \mathrm{ml}$ Table (3).

The results of SLF cell cloning in methotrexate medium are showed in Table (3). MTX -resistant cells had a plating efficiency of $17.2 \%$ of the wild type at $2.5(\mu \mathrm{g} / \mathrm{ml})$ of MTX. however, these were reduced to $4.4 \%$ at the $10(\mu \mathrm{g} / \mathrm{ml})$ of this antifolate drug. The mutation fraction of MTX-resistance was $22 \times 10^{-3}$ (events/gene ration /cell) at 10 $\mu \mathrm{g} / \mathrm{ml}$ of MTX..The phenotypic expression of these mutations was stable when the cells were grown for more than 8 weeks in MTX-medium.

The events that lead to the cytotoxic action of MTX begin with drug movement across cellular membrane, followed by its intracellular metabolism to the polyglutamate derivative, binding to dihydrofolate reductase (DHFR) and other folate dependent enzymes and finally initiating DNA synthesis. The possibility that naturally occurring DHFR alleles may exist in a variety of tissues was reported [25]. The DHFR genetic polymorphism may serve as a mechanism by which the cells may become MTXresistant (i.e. amplification of MTX insensitive alleles). In addition to gene amplification, more subtle mechanisms exist for increasing DHFR expression in the presence of MTX [26].Thus the mechanisms of MTX-resistance includes DHFR gene mutation, amplification of target gene, altered drug transport, differences in nucleosides and nucleobase salvage pathway [27].

These results suggested that SLF cells have spontaneous DHFR gene mutation (gene amplification). Within normal levels as in other cells [16] further investigation is required for determination of the DHFR enzyme activity in different MTX-resistant cells.

Thus we achieved the establishment of HPRT and DHFR gene-mutation assay as biomarkers for checking genome stability of animal cells for nuclear transfer techniques.

\section{References}

1. Szyblaska EH, and Szyblaski w (1962) Geneties of human cell line .Proc Natt Acad .Sci. (USA) 60:2026-2030.

2. Caskey CT and Kruch GD (1979). The HPRT locus. Cell 16:1-9.

3. Blakley R.L (1969) The biological reduction of peteridines, In "The Biochemistry of folic Acid and Related Pteridines .ed .A Neuberger and E.T. Tatum PP 139-187.

4. Korenberg A and Baker TA (1992) Biosynthesis of DNA precursors in DNA Replication 2nd ed .PP 53-100.

5. Blakley R.L (1984) Dihydroflate reductase .In Folates and pteridines .ed.RL.Blakley and S.J. Benkovic .Vol.1PP 191-253.

6. Kuyper LF (1990) Receptor -based design of DHFR inhibitor. In prtein Design and Development of New Therapeutics and vaccines ed. J.B.Hook and G.post PP297327. 
7. Blakley RL (1995) Eukaryotic DHFR .In "Advances in Enzymology and Related Areas of Molecular Biology". ed A.Meister Vol70PP 23-102

8. Anagnon NP, O Brien SJ, Shimada T., and Nask WJ (1984). Chromosomal organization of the human dhfr genes Proc. Natl. Acad. Sci 81: 5170-5174.

9. Shubber EK,Nada and Jafer ZMT (2001 a). Karyotyping of human lymphoblastiod cell line (GM-7254) Ibn AL-Haitham J. for Pure and APPL Sci.14:1-6.

10. Shubber EK,Jaffer ZMT,Abdul karim A., and Sebah MI (2001 b). Culturing of goat blood lymphocytes in vitro for cytogenetic analysis.Proc.1st Sci.Conf.National Board Biotech. Research Baghdad,September 18-19,PP11-23.

11. Puck,T.T., Marus P.I., and Cieciura S.J. (1956) Clonal growth of mammalian cells in vitro. J.Exp.Med.103,273-283.

12. Gey GO, Coffan WD, and Kubicek MT (1952). Tissue culture studies of the proliferative capacity of cervical carcinoma and nomal epithelium. Cancer Res. 12: 364-365.

13. Shubber EK,Auda HM,Jafar ZMT ,and Abdul -Rahman MH (1999) Phenotypic expression of three genetic markers in human lymphoblastoid cell lines (GM-7254) treated with MMC. The Nucleus 42:122-130.

14. Tilly WG,Delua JG,Frth EE,Hoppe H,Kaden DA, and Penman BW (1980) Gene Locus mutation assays in diploid human lymphoblast cell lines. In "Chemical mutagenesis . Ed. F. J. De Serries, A. Hollander $\underline{6}$ : pp331-364.

15. Shubber EK (1981) Genetic Hazard of Ten Antiparasitic Drugs Compared To Radiation .Ph.D Thesis ,Harvard University Cambridge, Mass.USA

16. Jaffer ZMT, Shubber EK, and Amash HM (2001) Cytogenetic analysis of Chinese lung fibroblasts spontaneously resistant to methotrexate. The Nucleus 44:28-35.

17. Shubber EK, Karm D, and Williams JR (1986) Comparison of the Ames assay and the detection of SCE Result with Ten pharma ceuticals and five selected agents .Cell Biol .Toxicol .2 379-399

18. Shubber EK, Altaif K I,AL Khateeb,G,Saltan AF,khaleel AH,Salman MS,L-Alaak BMA, and AL-Zuhairy (1992) Cytogenetic studies on blood lymphocytes from sheep infected with F. gigantica and treated with Albandazol .Iraqi. J.Vet .Med.15:10-24.

19. Shubber EK,Jaffer ZMT,Abdul karim A., and Sebah MI (2001) Culturing of goat blood lymphocytes in vitro for cytogenetic analysis.Proc.1st Sci.Conf.National Board Biotech. Research Baghdad,September 18-19,PP11-23.

20. Shubber EK, Jaffer ZMT, Nada SM, and Karma AH (1998) induction of chromosomal anomalies and gene amplification in human cells by anti-cancer drugs .The Nucleus 41,120-127.

21. Maybaum. J. and Mandel HG (1981). Differential chromatid damage induced by 6thiognanine in CHO cells Exp.Cell Res.135: 465-472.

22. Armstrong RD., Vera R., Synder P., And Cadman E. (1983). Enzyme and protein inhibitors. Biochem . Biophys. Res. Commun. 109: 595-608. Gey GO, Coffan WD, 
and Kubicek MT (1952). Tissue culture studies of the proliferative capacity of cervical carcinoma and nomal epithelium. Cancer Res. 12: 364-365. 